\section{POSITION OF THE METRIC SYSTEM.}

$\mathrm{I}$ may now be said that the metric system of weights 1 and measures is preferred by every Government in the world outside the British Empire, and that in this advance there has been no retreat.

Its opponents say that though foreign Governments may prefer the reform, it is fairly practised only in a few countries. The truth about this alleged discrepancy between law and popular usage is to be found in two parliamentary papers (Cd. $25^{8}$ of 1900 and $\mathrm{Cd}$. 435 of 1901), also partly in the records (Paris: Gauthier-Villars, 1907) of the last International Metric Conference, where England had two representatives.

Let us consider, first, the nations which have made least progress. The United States of America have not gone far-far enough, nevertheless, to decide their future, for there is no record of a reverse either in public opinion or practice, except, perhaps, in Turkey, where the Government applied violent coercion to an ignorant populace. Many public Acts of the United States show that their method of progress is to accustom, first their officers and then the public, to the new system before applying it to commerce. Accordingly, it has been introduced with great ease and success into the medical services of the army, navy and public health. There was no trouble, even in the difficulties of war with Spain, when civilian physicians, accustomed only to the old system, were enrolled for service. In some American cities medical prescriptions are by choice almost all metric. Electrical quantities, and to some extent electrical machinery, are metrically described, and metric standards, furnished by the International Bureau at Paris, are alone legal as the ultimate tests of American units. The United States have maintained the metric system in Cuba, Porto Rico, and the Philippines. Russia established it with complete success for all purposes in Finland sixteen years ago, and for the medical services of the Imperial Army and Navy last year. In 1907 it was reported at the International Conference to be spreading "rapidly and without opposition" throughout the Empire under the special direction of Privy Councillor M. Egoroff.

The Chinese Empire may be quoted, like other Governments, as conmitted to the metric system. After consideration, it has during the past year decided to alter the chief linear unit (chih) to $3^{2}$ centimetres, as a step towards metric reform, and this was done in face of a petition from too British merchants in favour of a British unit.

Japan, also, has recently given effective approval to the metric system by legalising it, teaching it in the primary schools, and using it for the medical services of the army and navy, also for scientific work. At the Paris conference of 1907 " legislation for its definite adoption" was announced to be in preparation. Meanwhile, tens of thousands of metric standards were being issued by the Government. British units are also used for engineering and for imported machinery.

On and after April I of next year taxes and customs dues in Denmark will be based on the metric system. The system will become general and obligatory on April $\mathrm{r}$, I9I2.

It is thus seen that these five Powers, the slowest to move, have approved, but do not yet largely practise, the metric system. The rest of the world, outside the British Empire, both approves and practises, excepting Turkey, Greece, some of the smaller South American republics, and various savage regions.

Notwithstanding what has been said above, some antimetricists declare that even in France the system is largely discarded. The answer to this is that old names are sometimes applied to metric units, e.g. the half-kilo. is sometimes called the livre, just as we call twenty-one shillings a guinea, and, secondly, textile goods of English sizes and marks go largely into foreign countries, and are even made there, just as motor-cars and electric machinery of metric size are found in England. There is no sign of metric failure in this, because in a metric country everything is sold metrically.

Even within the British Empire the self-governing colonies are eager for the reform. Australasia and New Zealand have twice urged it upon England, and New Zealand has recently legislated for the purpose. South
Africa has suggested it, and the Canadian Government has employed a lecturer to popularise it.

In presence of the above-stated facts, there is obvious danger that England may soon be isolated even from her English-speaking kinsfolk in the matter of weights and measures, notwithstanding the vain suggestion of an Anglo-Saxon conference to improve the British system and retain it in concert with America. There is India, of course, on which we could force any system, wise or foolish, for chaos rules there, and the situation is tolerated partly because full-weight silver coins serve as standard weights, and liquids are generally weighed. The kilogram was legalised for official use and railways on the advice of General Sir R. Strachey in 1871 , and the death of Lord Mayo alone prevented its introduction. India deserves better treatment, for it is to her that we owe, through the Arabs, not only the ten numeral figures, but probably also the device whereby both the form and position of each fix its meaning.

The cost and trouble of change are the chief real objections, so it is of the highest importance to remember that metricists do not propose to force the reform into factories, industries, or private life, but only into buying and selling. Cloth, yarn, ironwork, and everything could be made of any size or weight, but in the market such size or weight, if stated, would have to be in metric figures. There would be no alteration of count, number, pattern, or mark under which cloth, yarn, screws, \&c., are often sold. In private life the glass of beer, the teaspoonful of medicine, \&c.. would remain.

Shopkeepers and merchants, probably also railways, would be compelled to use new weights and yard sticks, and their example would quickly educate the whole country. No more than this limited compulsion was proposed to Parliament in 1907 , but objectors presented estimates of cost based on universal compulsion, and the result was an adverse vote of 150 against 118 . The House of Commons had not then before it the evidence afterwards given at the Paris International Conference, that commerce can be metric without impeding industry.

There is, however, a considerable class of people who can never be converted except perhaps by fear of international isolation. Therefore, pending another attempt at legislation, the converted should practise their faith rather than preach it to the deaf. Scientific societies and scientific departments of State could favour metric usage, as the British Medical Association is now doing, and as the Government might do in the medical services of its army, navy, and public health, unless it distrusts the American experience above stated.

In meteorology, geology, and cartography there is much room for advance, excepting the excellent maps with scales of $x / 2500$ and $r / 5000$.

There is not space here for the long array of great names which support this reform, and it ought to be needless to state that the system does not embrace angles, time, navigation, thermometry, money, or anything but measures of length, surface, volume, and weight. Nevertheless, it may be mentioned that one of its principles, the counting by tens, which abolishes compound arithmetic, would save here, as in all foreign countries, a vast total of human energy, especially in application to money. It is estimated that in the Custom House alone decimalised money would save $20,000 l$. a year.

\section{BIRD-LIFE.}

THE feeding-habits of the dunlin form the subject of a paper-based on close personal observation-contributed by Mr. J. M. Dewar to the January number of the Zoologist. In surface-feeding these attractive birds search for small organisms floating in the wash of the sea or carried seawards by the shore-streams, as well as for minute insects and spiders on the sand or mud, although the main objects of their quest are tiny univalve molluscs, with the shells of which their gizzards are always crammed. Dead shells, which form a large proportion of those on most shores, are left alone. Dunlins also probe the sand or mud for bivalve molluses and worms. Both in the act of tapping and probing the two halves of the

NO. 2052, VOL. 79] 